\title{
Efficiency of Some Anticoagulants Against The Albino Norway Rat, Rattus Norvegicus Under Laboratory Conditions
}

Asran, A. A.; Fatma K. Khidr ; Mona A. Ali and Nadia M. S. El-Hawashy

Plant Protection Research Institute - Agricultural Research Center, Dokki, Giza, Egypt.

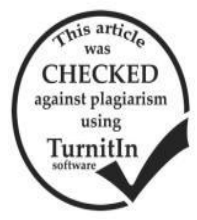

\section{ABSTRACT}

This work aim to clear the effect of $\mathrm{LD}_{50}$ values of varied anticoagulants on the body weight reduction, day to death and appetency percentage for male, female and juvenile of the albino Norway rat, $R$. norvegicus under laboratory conditions. The gained results could be concluded as next: The $\mathrm{LD}_{50}$ values of the treated male, female and juvenile of $R$. norvegicus with each of Bromadiolone, Difenacoum and Chlorophacinone were; (0.81, 0.91 and $0.78 \mathrm{mg} / \mathrm{kg} \mathrm{b.w.)},(1.40,1.54 \mathrm{and} 1.27 \mathrm{mg} / \mathrm{kg} \mathrm{b.w.)} \mathrm{and}$ $(6.02,6.13$ and $5.92 \mathrm{mg} / \mathrm{kg}$ b.w.), respectively. These figures proved that adult male was more susceptible than female for the whole tested anticoagulants, meanwhile juvenile was more susceptible than adult. The body weight reduction percentages for male, female and juvenile were; (13.9, 10.7 and 14.3\%), (21.8, 13.7 and 13.5\%) and (10.2, 10.9 and 18.2\%) for Bromadiolone, Difenacoum and Chlorophacinone, respectively. In addition, mean day to death of the treated individuals with $\mathrm{LD}_{50}$ values of Bromadiolone, Difenacoum and Chlorophacinone were (6.0, 6.0 and 4.6 days), (4.0, 6.0 and 4 day) and (6.8, 6.6 and 4.5 day) respectively. In other words, Difenacoum was the most effective one against the experimental individuals followed by Bromadiolone and Chlorophacinone. Also, the results proved that the adult (male and female) and juvenile which treated with the tested anticoagulants lost their appetite for the introduced plain food after the treatment gradually. As well as, the data cleared that there is a positive link between appetency percentage and the body weight reduction for adult (male and female) and juvenile both of $R$. norvegicus.

\section{INTRODUCTION}

Rodents cause untold economic loss to farmers, food manufacturers and processors as well as causing damage to the structure and buildings fabric. Undoubted by the economic loss due to rodents is enormous particularly in the tropics, but it is impossible to exact monetary values on the damaged caused. The World Health Organization estimates that about 33 million tons of food is destroyed world-wide each year.

The use of toxicants of chemical pesticides had been relatively ineffective, due to poison shyness, or behavioral resistance, developing as results of the rapid onset of poisoning symptoms before ingestion of a lethal dose had occurred (Grand, 1976), (Ophof and Langeveld, 1969) and (Wang, 1978). Despite the fact that chemical control of rodents has been practiced for more than 2000 years, It was only 35 years ago that the introduction of anticoagulant rodenticides revulationised the efficacy and safety control of rodents (Dubock, 1979). The majority of anticoagulants chemically belong to coumarin group. Naturally coumarins are present in plants in free as well as conjugated group (Hagen et al., 1967).

This work aims to spot light on effect of each of Bromadiolone, Difenacoum and Chlorophacinone on some aspects such as; day to death, body weight reduction and appetency percentage of albino Norway rat, Rattus norvegicus, var. albino for adult (male and female) and juvenile to determine the suitable chemical compound for each of sex and age to apply it for gain a good control.

\section{MATERIALS AND METHODS}

\section{Experimental design:}

\section{1-Anticoagulants used:}

Three anticoagulant rodenticides were tested during this study, i.e. Bromadiolone, Difenacoum and Chlorophacinone which were obtained from Glaxo wellcome U.K. Besiers, France and ICI companies, respectively.

\section{Bromadiolone (0.005 \%) \\ - Chemical name: \\ 3-[3-(4-Bromo1,1-biphenyl-4-yl)-3-hydroxy-}

1-phenylpropyl]-4-hydroxy-2H-1-benzopyran-2-one

Difenacoum (93\%)

- Chemical name:

3-(3-biphenyl-4-yl-1， 2, 3, 4-tetrahydro-1-naphthyl)4-hydroxycoumarin

Chlorophacinone (85\%)

- Chemical name:

2- [2-(4-Chlorophenyl)-2-phenylacetyl]indan-1,3-dione Formulation:

Readymade, Wax blocks, Tracking powder and liquid.

\section{2- Tested animals:-}

Albino adults of Norway rat, Rattus norvegicus were obtained from culture of Experimental Animals in Helwan, (Egyptian Organization for Biological Products and Vaccine). Rats were individually reared, acclimatized under laboratory conditions. Active and healthy rats of both sexes were chosen for mating to obtain a healthy offspring. The resultant offspring were fed on a standard laboratory ration. The active, healthy juvenile and adult (male and female) were randomly chosen and separated into three groups. The first group was treated with Bromadiolone while, the second was treated with Difenacoum and the third group was treated with Chlorophacinone.

\section{3- Parameters evaluated:-}

\section{3-a- Determination of $\mathbf{L D}_{\mathbf{5 0}}$ values:}

Serial different doses of the various rodenticides, Bromadiolone (0.6, 0.8, 1.0, 1.2, and 1.4); Difenacoum (1.0, 1.5, 2.0, 2.5 and 3.0) and Chlorophacinone (5.75, $6.0,6.25,6.50$ and 6.75$)$ active ingredient calculated as $\mathrm{mg} / \mathrm{kg}$ body weight were used, after mixing well with one drop of Tween 80 and dissolved in distilled water. Four adults of each male, female and juvenile rat caged individually, were used for each dose administrated by oral intubation. A parallel control test was conducted using solvent (distilled water) for the rodenticides tested. Mortality percentages were recorded up to 28 days post- treatment. 
3-b- Determination the appetency, body weight reduction and day to death:

The adult male, female and juvenile of the albino rat $R$. norvegicus were treated with the calculated $\mathrm{LD}_{50}$ values for the different tested rodenticides; Bromadiolone, Difenacoum and Chlorophacinone orally. The treated individuals caged invidually and fed on the plain whole wheat grains for 28 days after the treatment. They were observed daily to record the dead one to calculate the day to death. The consumed amount from the plain food by the experimental animals were weighed before $/$ after $1^{\text {st }}, 3^{\text {rd }}, 5^{\text {th }}$ and $7^{\text {th }}$ day from the treatment to estimate the appetency percentage of the tested animals. The tested animals weighed before and after treatments to compute their body weight reduction. The appetency percentage was calculated by the following formula:

$$
\text { Appetency \% }=\frac{A-B}{A} X 100
$$

Where:

$$
\begin{aligned}
& \mathrm{A}=\text { consumption bait before treatment } \\
& \mathrm{B}=\text { consumption bait after treatment }
\end{aligned}
$$

\section{Statistical analysis:}

$\mathrm{LD}_{50}$ values for the tested anticoagulants on each of male, female and juvenile $R$. norvegicus were calculated by probit regression analysis. Also analysis of variance and T-test were calculated by using Finney (1971) and slide write and COSTAT programs.

\section{RESULTS AND DISCUSSION}

This work aim to clear the effect of $\mathrm{LD}_{50}$ values of varied anticoagulants on the body weight reduction, day to death and appetency percentage for male, female and juvenile of the albino Norway rat, $R$. norvegicus under laboratory conditions. The tabulated results in Table (1) represented the mortality percentage and $\mathrm{LD}_{50}$ values. The $\mathrm{LD}_{50}$ values of the treated male, female and juvenile of $R$. norvegicus with each of Bromadiolone, Difenacoum and Chlorophacinone were; $(0.81,0.91$ and $0.78 \mathrm{mg} / \mathrm{kg}$ b.w.), (1.40, 1.54 and $1.27 \mathrm{mg} / \mathrm{kg}$ b.w.) and (6.02, 6.13 and $5.92 \mathrm{mg} / \mathrm{kg}$ b.w.), respectively. These figures proved that adult male was more susceptible than female for the whole tested anticoagulants, meanwhile, juvenile was more susceptible than adult. As well as, the recorded results for slope in Table (1) cleared that the tested individual were homogenetical for female (0.93) for Bromadiolone whereas; juvenile was homogentical in case of Difenacoum (0.91) and Chlorophacinone (0.79). This means that the tested juvenile individuals were the most homogenetical than adults (male and female). This result agreed with Nancy and Neena (2014) which reported that female house rat, (Rattus rattus) were more tolerant to Bromadiolone toxicity than male rats, where $\mathrm{LD}_{50}$ values of active ingredient were found to be 1.05 and $1.83 \mathrm{mg} / \mathrm{kg} \mathrm{b}$. w. for male and female rats, respectively. Abou-Hashem (2007) found that males of $R$. norvegicus which fed on either mixture of wheat and maize or vegetables were more tolerant than females approximately. In addition, he also, cleared that both sexes of $R$. norvegicus which fed on mixture of wheat and maize were more susceptible to Chlorophacinone than Brodifacoum and Warfarin. In spite of, the tested animals which fed on vegetable were more susceptible to Brodifacoum, they had tolerance to Warfarin.

\begin{tabular}{|c|c|c|c|c|c|c|c|c|c|c|}
\hline \multirow[b]{2}{*}{ Rodenticides } & \multirow{2}{*}{$\begin{array}{c}\text { Doses } \\
\mathrm{mg} / \mathrm{kg} \text { b. w. }\end{array}$} & \multicolumn{3}{|c|}{ Mortality (\%) } & \multicolumn{3}{|c|}{$\mathbf{L D}_{50}$ value } & \multicolumn{3}{|c|}{ Slope } \\
\hline & & $\hat{0}$ & q & Juv. & 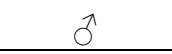 & q & Juv. & 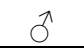 & 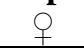 & Juv. \\
\hline \multirow{5}{*}{ Bromadiolone } & 0.6 & 27 & 18 & 27 & $\begin{array}{c}0.81 \\
(0.64-0.93)\end{array}$ & $\begin{array}{c}0.91 \\
(0.75-1.1)\end{array}$ & $\begin{array}{c}0.78 \\
(0.64-0.84)\end{array}$ & 0.67 & 0.93 & 0.78 \\
\hline & 0.8 & 45 & 36 & 45 & & & & & & \\
\hline & 1.0 & 64 & 55 & 73 & & & & & & \\
\hline & 1.2 & 81 & 73 & 91 & & & & & & \\
\hline & 1.4 & 100 & 91 & 100 & & & & & & \\
\hline \multirow{5}{*}{ Difenacoum } & 1.0 & 27 & 18 & 27 & $\begin{array}{c}1.40 \\
(1.07-1.65)\end{array}$ & $\begin{array}{c}1.54 \\
1.23-1.81)(\end{array}$ & $\begin{array}{c}1.27 \\
(0.99-1.48)\end{array}$ & 0.30 & 0.69 & 0.91 \\
\hline & 1.5 & 55 & 45 & 64 & & & & & & \\
\hline & 2.0 & 64 & 64 & 91 & & & & & & \\
\hline & 2.5 & 100 & 91 & 100 & & & & & & \\
\hline & 3.0 & 100 & 100 & 100 & & & & & & \\
\hline \multirow{5}{*}{ Chlorophacinone } & 5.75 & 27 & 18 & 27 & $\begin{array}{c}6.02 \\
(5.91-6.17)\end{array}$ & $\begin{array}{c}6.13 \\
(5.95-6.27)\end{array}$ & $\begin{array}{c}5.92 \\
(5.77-6.15)\end{array}$ & 0.77 & 0.77 & 0.79 \\
\hline & 6.0 & 55 & 36 & 45 & & & & & & \\
\hline & 6.25 & 64 & 55 & 64 & & & & & & \\
\hline & 6.50 & 91 & 82 & 91 & & & & & & \\
\hline & 6.75 & 100 & 100 & 100 & & & & & & \\
\hline
\end{tabular}

Table (1): Mortality percentages of Rattus norvegicus treated with serial varied doses of certain anticoagulants and its $\mathbf{L D}_{50}$ values.

Effect of $\mathrm{LD}_{50}$ values of some anticoagulants on body weight of Rattus. norvegicus and day to death:

The recorded data in Table (2) show the body weight reduction and day to death of the albino Norway rat (male, female and juvenile) because of treated them with $\mathrm{LD}_{50}$ values of Bromadiolone, Difenacoum and Chlorophacinone. These data revealed that the body weight reduction percentages for male, female and juvenile were; (13.9, 10.7 and 14.3\%), (21.8, 13.7 and 
$13.5 \%)$ and (10.2, 10.9 and 18.2\%) for Bromadiolone, Difenacoum and Chlorophacinone, respectively.

The body weight reduction percentage ranged between $10.2 \%$ for male which treated with $\mathrm{LD}_{50}$ values of Chlorophacinone and $21.8 \%$ for male which treated with $\mathrm{LD}_{50}$ value of Difenacoum. The gained figures have no accurate rule for different tested sex and age of $R$. norvegicus. Keshta (2006) proved that the rate of the body weight reduction and its percentages of the albino house mouse Mus musculus, who fed on warfarin $(0.02 \%$ hydroxyl coumarin) for 4 days under both tests non choice and choice were (-3.2 gm and 9.9\%) and $(-2.0 \mathrm{gm}$ and $7.3 \%)$ and were $(-1.1 \mathrm{gm}$ and $3.7 \%)$ and $(-3.8 \mathrm{gm}$ and $13.3 \%)$ for males and females respectively. The gained results show the general average of mice body weight reduction for non choice test was $(-2.6 \mathrm{gm}$ and $8.6 \%)$ and was $(-2.5 \mathrm{gm}$ and $8.5 \%$ ) for choice test.

On the other hand, the figures in Table (2) represents day to death of varied age and sex of the albino Norway rat because of intubation orally with varied anticoagulants. Mean day to death of the treated individuals with $\mathrm{LD}_{50}$ values of Bromadiolone, Difenacoum and Chlorophacinone were respectively; (6.0, 6.0 and 4.6 days), (4.0, 6.0 and 4 day) and (6.8, 6.6 and 4.5 day). These findings proved that Difenacoum was the most effective one against the experimental individuals followed by Bromadiolone and Chlorophacinone. Keshta(2006) reported that the longest time to death in day was 11 and shortest was 6 days with average 8.3 days for males and it was 7.0 in females for non choice test. Meanwhile the time to death under choice test was (6 and 10 days) for males and females of Mus musculus. The general average of time to death in both obliged and free tests were respectively, 7.7 and 8.0 days. Greaves et al., (1974) estimated that the whole tested rat and mice which fed on $0.1 \%$ Calciferol for 2 days died. Illness usually reduced food intake after the first $24 \mathrm{hr}$. Poison at $0.1 \%$ which is considered to be the lowest concentration suitable for use against Rattus norvegicus and Mus musculus.

Table (2): Effect of $\mathrm{LD}_{50}$ values of some anticoagulants on body weight of Rattus. norvegicus and day to death.

\begin{tabular}{|c|c|c|c|c|c|c|c|}
\hline \multirow{2}{*}{ Rodenticides } & \multirow{2}{*}{ Status } & \multirow{2}{*}{$\begin{array}{l}\text { Tested dose } \\
\text { LD }_{50}\end{array}$} & \multicolumn{3}{|c|}{ Body weight (g) } & \multicolumn{2}{|c|}{ Day to death } \\
\hline & & & Before & After & \% Redaction & Mean & Range \\
\hline \multirow{3}{*}{ Bromadiolone } & $\hat{0}$ & 0.81 & 239.4 & 206.0 & 13.9 & 6.0 & $5-7$ \\
\hline & q & 0.91 & 204.0 & 182.2 & 10.7 & 6.0 & $5-7$ \\
\hline & Juv. & 0.78 & 81.9 & 70.4 & 14.3 & 4.6 & $3-6$ \\
\hline \multirow{3}{*}{ Difenacoum } & $\widehat{\jmath}$ & 1.40 & 262 & 205 & 21.8 & 4.0 & $5-6$ \\
\hline & q & 1.54 & 197 & 170 & 13.7 & 6.0 & $5-7$ \\
\hline & Juv. & 1.27 & 80.9 & 70.0 & 13.5 & 4.0 & $3-5$ \\
\hline \multirow{3}{*}{ Chlorophacinone } & $\hat{0}$ & 6.02 & 260.4 & 233.8 & 10.2 & 6.8 & $6-7$ \\
\hline & q & 6.13 & 216.6 & 193.0 & 10.9 & 6.6 & $6-7$ \\
\hline & Juv. & 5.92 & 94.3 & 77.1 & 18.2 & 4.5 & $3-6$ \\
\hline
\end{tabular}

Effect of $\mathrm{LD}_{50}$ values of some anticoagulant on appetency \% of Rattus norvegicus:

The consumed amount from the introduced plain food (the whole wheat grains) by the male of experimental animals after $1^{\text {st }}, 3^{\text {rd }}, 5^{\text {th }}$ and $7^{\text {th }}$ day from the treatment with tested anticoagulants; Bromadiolone, Difenacoum and Chlorophacinone were; (19.3, 13.8, 12.3 and $7.5 \mathrm{~g}),(21.0,16.4,11.1$ and $8.4 \mathrm{~g})$ and $(18.5$, $16.7,14.3$ and $17.7 \mathrm{~g}$ ), respectively (Table 3 ).

Whereas, the consumption by females for the same chemicals ranged between $18.3 \mathrm{~g}$ (Chlorophacinone) to $15.6 \mathrm{~g}$ (Difenacoum) after one day from the treatment. For juvenile, the highest and lowest consumed amount were; $9.8 \mathrm{~g}$ (Chlorophacinone) and $7.1 \mathrm{~g}$ (Bromadialone) after one day from the treatment, successively. On the other hand, the compiled data in Table (3) revealed that, the appetency percentages for each of male, female and juvenile after $7^{\text {th }}$ day from the treatment were; $(62.9 \%, 50 \%$ and $48.2 \%)$ for Bromadialone, $(61.5 \%, 71.7 \%$ and $54.1 \%)$ for Difenacoum and $(17.3 \%, 13.3 \%$ and $33 \%)$ for Chlorophacinone. These figures proved that the adult (male and female) and juvenile which treated with the tested anticoagulants lost their appetite for the introduced plain food after the treatment gradually. The appetency percentage decreased slightly at $1^{\text {st }}$ day from the treatment and was a drastic at $7^{\text {th }}$ from the treatment.
In addition these data proved that there is a positive link between the appetency percentage and the body weight reduction for both adult (male and female) and juvenile of $R$. norvegicus.

Asran et al., (2001) reported that the consumed quantities of Racumine and Malathion mixture by male were more than female of Rattus norvegicus for the whole tested concentration $(1: 5,1: 10$ and 1:15). In general, average of the consumed quantity of Racumine / Malathion tracking powder had a negative correlation ship with the tested concentration. Moreover, the highest and the lowest consumed amount of Racumine / Malathion mixture by the adult of the Norway rat, Rattus norvegicus were $42.0 \mathrm{gm} . / \mathrm{kg} /$ day $(1: 15$ Concentration ) and $25.0 \mathrm{gm} . / \mathrm{kg} /$ day $(1: 10$ concentration). EL-Nashar (1998) mentioned that, the consumed amount from olive oil, soy-bean oil, cotton seeds oil baits by five males of the albino Norway rat, Rattus norvegicus Berken, for three successive days were 60.9, 74.0, $66.2,47.5$ and $45.8 \mathrm{~g}$, respectively and were $69.0,70.4,60.9,53.7$ and $59.4 \mathrm{~g}$ for females, successively. Hadler (1975) found that mean daily bait consumed by Rattus rattus when choice fed $26.0 \mathrm{gm}$. $/ \mathrm{kg}$. b.w. I day from the poisoned bait (0.005\%) Difenacoum and $16 \mathrm{gm}$. $/ \mathrm{kg}$.b.w. / day from the normal food. 
Asran, A. A. et al.

Table (3): Effect of $\mathrm{LD}_{50}$ values of some anticoagulant on appetency \% of Rattus norvegicus.

\begin{tabular}{|c|c|c|c|c|c|c|c|c|c|}
\hline \multirow[t]{2}{*}{ Rodenticides } & \multirow[t]{2}{*}{ Status } & \multirow{2}{*}{$\begin{array}{l}\text { Tested dose } \\
\quad\left(\mathrm{LD}_{50)}\right.\end{array}$} & \multicolumn{5}{|c|}{ Bait consumption $(\mathrm{g})$} & \multicolumn{2}{|c|}{$\begin{array}{c}\text { Appetency }(\%) \text { after } \\
\text { treatment at }\end{array}$} \\
\hline & & & Before treatment & $\mathbf{1}^{\mathrm{st}}$ & $\underset{3^{\text {rd }}}{\operatorname{After} \text { tr }}$ & $\underset{5^{\text {th }}}{\text { eatmen }}$ & $7^{\text {th }}$ & $1^{\text {st }}$ day & $7^{\text {th }}$ day \\
\hline \multirow{3}{*}{ Bromadiolone } & $\sigma^{\lambda}$ & 0.81 & 20.2 & 19.3 & 13,8 & 12.3 & 7.5 & 4.5 & 62.9 \\
\hline & 우 & 0.91 & 19.3 & 17.9 & 15.8 & 13.1 & 8.4 & 7.3 & 50.0 \\
\hline & Juv. & 0.78 & 8.3 & 7.1 & 6.0 & 5.0 & 4.3 & 14.5 & 48.2 \\
\hline \multirow{3}{*}{ Difenacoum } & $\hat{0}$ & 1.40 & 21.8 & 21.0 & 16.4 & 11.1 & 8.4 & 3.7 & 61.5 \\
\hline & $q$ & 1.54 & 17.3 & 15.6 & 12.9 & 9.0 & 4.9 & 9.8 & 71.7 \\
\hline & Juv. & 1.27 & 8.5 & 7.3 & 6.1 & 5.0 & 3.9 & 14.1 & 54.1 \\
\hline \multirow{3}{*}{ Chlorophacinone } & $\hat{\sigma}$ & 6.02 & 21.4 & 18.5 & 16.7 & 14.3 & 17.7 & 13.6 & 17.3 \\
\hline & o & 6.13 & 18.8 & 18.3 & 18.4 & 17.7 & 16.3 & 2.7 & 13.3 \\
\hline & Juv. & 5.92 & 10.9 & 9.8 & 8.5 & 7.9 & 7.3 & 10.1 & 33.0 \\
\hline
\end{tabular}

\section{REFERENCES}

Abou-Hashem, A.A.M. (2007): Susceptibility of the albino Norway rat, Rattus norvegicus to certain anticoagulant rodenticides. J. Agric. Sci. Mansoura Univ., 32 (4): 3029-3035.

Asran, A.A; Metwally, A.M.; Abd EL-Kariem, S.M. and Abou-Hashem, A.A. (2001): Effect of certain concentration of Racumine $(0.0375 \%)$ and Malathion (1\%) as a tracking powder on some rodents under laboratory conditions. Egypt J. Appl. Sci., 16 (4): 321-331.

Dubock, A.C. (1979): Alternative strategies for safety and efficacy of rodenticides. Proc. $5^{\text {th }}$ Br. Pest control conf. Stratford - upon Avon. 9: 26-29.

EL-Nashar, M.A. (1998): Ecological and Toxicological studies on some Egyptian rodents in certain traditional cultivated areas in some Governorates in Egypt. M.Sc. Thesis, Fac. of Agric. AL-Azhar Univ., pp. 232.

Finney, D.J. (1971): Probit analysis $3^{\text {rd }}$ edition Cambridge Univ., pp. 333.

Grand, M. (1976): Experimental results on a new anticoagulant rodenticide bromadiolone. Phytial. Phytopharm., 25 (1): 69-88.

Greaves, J.H.; Redfen, R. and King, R.E. (1974): Some properties of calciferol as rodenticides. J. Hyg. Comb., 73 (3): 341-351.
Hadler, M.R. (1975): Laboratory evaluation of difenacoum as rodenticide. J. Hyg. Comb., 75: 441-448.

Hagen, E.C.; Hansen, W.H.; Fitzhagh, O.G.; Jenny, P.M.; Jones, W.I.; Taylor, J.M.; Long, E.L.; Nelson, A.A. and Brouwer, G.B. (1967): Food flavorings and compounds of related structure. Subacute and chronic toxicity. Food Cosmet. Toxico., (5): 141.

Keshta, T.M. (2006): Efficiency of warfarin against certain albino rodents under laboratory conditions. J. Agric. Sci. Mansoura Univ., 31(2): 1021-1025.

Nancy G. and Neena S. (2014): Toxicity of second generation anticoagulant bromadiolone against Rattus rattus: individual and sex specific variations. Cibtech J. Zoology. 3 (2): 43-48.

Ophof, A.J. and Langeveld, D.W. (1969): Warfarin resistance in the Netherlands. Proc. Rodent Biology and control Meeting Berlin- Dahlem: 39-47.

Wang, P.Y. (1978): Studies on rat control in sugar cane plantation, poison efficacy trial of rodenticides. Progress Report of Taiwan sugar Research Institute: 363.

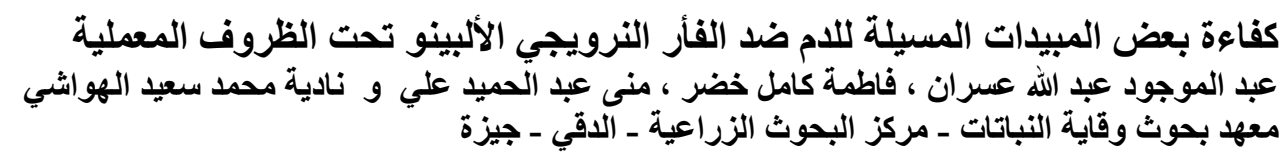

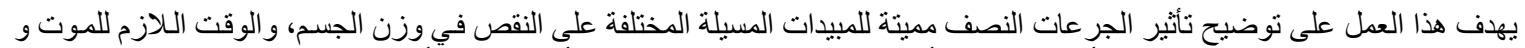

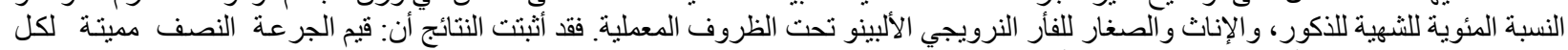

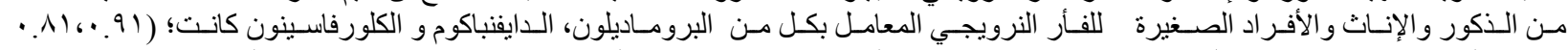

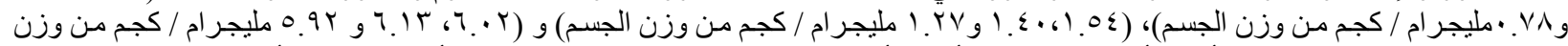

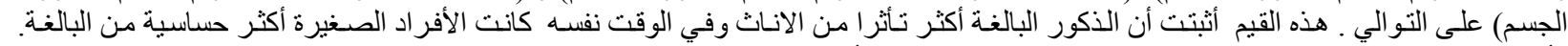

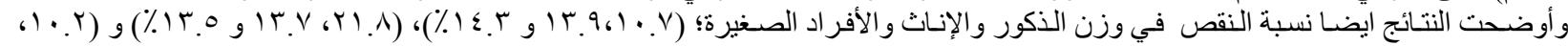

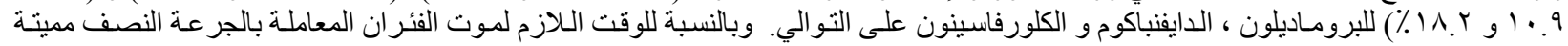

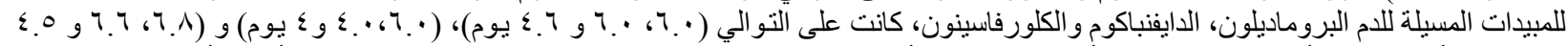

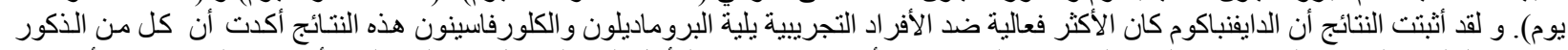

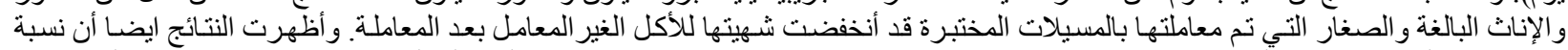

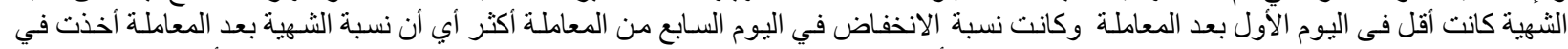

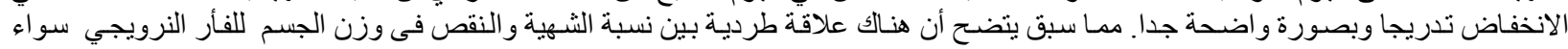
(ذكور ا و إناثا) البالغة و الصغار 